\title{
Cytotoxicity of Marchantia convoluta leaf extracts to human liver and lung cancer cells
}

\section{J.B. Xiao ${ }^{1,2}$, X.Q. Chen ${ }^{1}$, \\ Y.W. Zhang' ${ }^{2}$ X.Y. Jiang ${ }^{1}$ and $M . X u^{2,3}$}

\begin{abstract}
The cytotoxicity of three extracts (petroleum ether, ethyl acetate and n-butanol) from a plant used in folk medicine, Marchantia convoluta, to human non-small cell lung carcinoma (H1299) and liver carcinoma (HepG2) cell lines was tested. After 72-h incubation of lung and liver cancer cell cultures with varying concentrations of extracts ( 15 to 200 $\mu \mathrm{g} / \mathrm{mL})$, cytotoxicity was determined by the 3-(4,5-dimethylthiazol2-yl)-2,5-diphenyltetrazolium bromide assay and reported in terms of cell viability. The extracts that showed a significant cytotoxicity were subjected to gas chromatography-mass spectrometry analysis to identify the components. The ethyl acetate, but not the petroleum ether or n-butanol extract, had a significant cytotoxicity against lung and liver carcinoma cells with $\mathrm{IC}_{50}$ values of 100 and $30 \mu \mathrm{g} / \mathrm{mL}$, respectively. A high concentration of ethyl acetate extract $(100 \mu \mathrm{g} / \mathrm{mL})$ rapidly reduced the number of H1299 cells. At lower concentrations of ethyl acetate extract $(15,30$, and $40 \mu \mathrm{g} / \mathrm{mL})$, the numbers of HepG2 cells started to decrease markedly. Gas chromatography-mass spectrometry analysis of the ethyl acetate extract revealed the presence of several compounds such as phytol (23.42\%), 1,2,4-tripropylbenzene (13.09\%), 9-cedranone (12.75\%), ledene oxide (7.22\%), caryophyllene $(1.82 \%)$, and caryophyllene oxide $(1.15 \%)$. HPLC analysis result showed that there were no flavonoids in ethyl acetate extract, but flavonoids are abundant in n-butanol extract. Further studies are needed regarding the identification, toxicity, and mechanism of action of active compounds.
\end{abstract}

Received July 29, 2005 Accepted March 22, 2006
Key words

- Marchantia convoluta extract

- Cytotoxicity assay

- HepG2 and H1299

carcinoma cell lines

- Phytol

- Caryophyllene oxide

.....................

\section{Introduction}

Marchantiaceae plants are well-known traditional Chinese medicinal herbs extensively used to treat skin tumefaction, to protect the liver and to treat hepatitis, being also used as antipyretics (1-3). Large numbers of Marchantiaceae plants occur in Guangxi
Zhuang Autonomous District such as Marchantia polymorpha, M. convoluta and $M$. paleacea. Many studies on the chemical constituents and bioactivities of M. polymorpha have been reported (4-13). These species grow together and are difficult to distinguish from one another because of their genetic similarity. M. convoluta is only found in 
China (14) and is quite rare.

The major identified constituents of $M$. convoluta are flavonoids, triterpenoids and steroids (15-18). The flavonoids of M. convoluta consist mainly of quercetin, luteolin, apigenin, and their $O$ - and $C$-glycosides (15-17). A high dosage of flavonoids from $M$. convoluta (20 and $40 \mu \mathrm{g} / \mathrm{mL}$ ) can significantly reduce the activity of alanine aminotransferase and aspartate aminotransferase in the serum of mice with acute hepatic injury caused by $\mathrm{CCl}_{4}$ and increase the contents of total protein and alkaline phosphatase, as well as inhibit the auricle tympanitis of mice caused by dimethylbenzene (1). Flavonoids from $M$. convoluta strongly inhibit colibacillus, typhoid bacillus, Staphylococcus aureus, Bacillus enteritidis, hemolytic streptococci type B, and Diplococcus pneumoniae and have antibiotic, anti-inflammatory and diuretic effects on mice (1).

In the present study, the effects of extracts of $M$. convoluta on human carcinoma cells were investigated. Non-small cell lung carcinoma cell line H1299 and the liver cancer cell line HepG2 were used. Some of the chemical constituents of petroleum ether and ethyl acetate extracts were also identified by gas chromatography-mass spectrometry (GC-MS).

\section{Material and Methods}

\section{General}

Ethanol, petroleum ether, ethyl acetate, and n-butanol, all of analytical reagent grade, were purchased from Tianjin Damao Chemical Reagent Factory (Dongli District, Tianjin, China).

\section{Plant material}

The leaves of $M$. convoluta were collected in Shangling City, Guangxi Zhuang Autonomous District, China, in August 2003. The specimen (No. 20041364) was identified by Zhou Zi-jing at the Biology Depart- ment of Guangxi Chinese Medical University. The leaves were washed with water, dried in the shade for several days, and powdered.

\section{Preparation of plant extracts}

The powdered plant material (500 g) was extracted three times with $3000 \mathrm{~mL}$ ethanolwater $(1: 1, v / v)$. The accumulated alcoholic extract was concentrated to dryness under reduced pressure and extracted three times with petroleum ether $(100 \mathrm{~mL})$. The residue was extracted three times with ethyl acetate $(100 \mathrm{~mL})$. Then, the residue was extracted three times with n-butanol (100 mL). All extracts were then filtered and concentrated to dryness under reduced pressure. The yields of the petroleum ether extract, ethyl acetate extract and n-butanol extract were 4.61, 7.38, and $5.29 \%$ (w/w), respectively. All extracts were dissolved in $95 \%$ ethanol to form stock solutions that were sterilized by filtration $(0.2 \mu \mathrm{m})$ before testing.

\section{In vitro assay for cytotoxic activity}

Cell lines. Human non-small cell lung carcinoma cell line H1299 and human liver carcinoma cell line HepG2 were used. Cells were established and kindly provided by Dr. $\mathrm{Xu}$, Memorial Sloan-Kettering Cancer Center, New York) and were cultured in RPMI 1640 medium supplement with $10 \%$ heated fetal bovine serum, $2 \mathrm{mM}$ L-glutamine, 50 $\mathrm{IU} / \mathrm{mL}$ penicillin, and $50 \mu \mathrm{g} / \mathrm{mL}$ streptomycin and maintained at $37^{\circ} \mathrm{C}$ in a $5 \% \mathrm{CO}_{2}$ atmosphere with $95 \%$ humidity.

3-(4,5-Dimethylthiazol-2-yl)-2,5-diphenyltetrazolium bromide (MTT) assay. For the assay, cells were washed with phosphatebuffered saline (PBS) free of magnesium and calcium. The PBS was decanted, the cells were detached with $0.025 \%$ trypsinEDTA (Sigma, St. Louis, MO, USA) and PBS was added to a volume of $50 \mathrm{~mL}$. The cell pellet obtained by centrifugation was 
suspended in $10 \mathrm{~mL}$ of medium to prepare a single cell suspension. The density of viable cells was determined by Trypan blue exclusion in a hemocytometer and the preparation was then diluted with medium to yield previously determined optimal plating densities for H1299 and HepG2. The HepG2 and H1299 cells were seeded on 96-well plates at a final concentration of $5 \times 10^{4}$ cells per $100 \mu \mathrm{L}$ medium per well $24 \mathrm{~h}$ before the assay. The cell suspensions were then incubated at $37^{\circ} \mathrm{C}$ to permit cell attachment. After $24 \mathrm{~h}$ the cells were treated with the extracts. Each extract was initially dissolved in ethanol and $500 \mu \mathrm{g} / \mathrm{mL}$ of each extract was tested initially against both cancer cell lines. On the basis of the results obtained, extracts were considered to be active when they produced less than $50 \%$ survival after an exposure time of $72 \mathrm{~h}$. The active extracts were further diluted in medium to produce 7 concentrations of $0,15,30,40,50,100,200 \mu \mathrm{g} /$ $\mathrm{mL}$ of each extract and $100 \mu \mathrm{L} /$ well of each concentration was added to the plates in six replicates. At the end of the exposure time the medium was removed and MTT assays were then performed using the cell titer kit ${ }^{\mathrm{TM}}$ (Promega Corp., Madison, WI, USA). Twenty milliliters MTT $(5 \mathrm{mg} / \mathrm{mL})$ in PBS was incubated with cells on a 96-well plate for $2 \mathrm{~h}$ at $37^{\circ} \mathrm{C}$. Subsequently, the medium containing MTT was removed, and $100 \mathrm{~mL}$ acidified isopropanol $(0.04 \mathrm{~mol} / \mathrm{L} \mathrm{HCl})$ was added. The absorbance of each sample was measured at $570 \mathrm{~nm}$ using a microplate reader (Bio-Rad Laboratories, Orlando, FL, USA, model 3550). The data were normalized (A570 $\mathrm{nm}$ ) and the mean absorbance was plotted against drug concentration. Three replicate plates were used to determine the cytotoxicity of each extract.

\section{Gas chromatography-mass spectrometry}

GC-MS analysis was performed using an Agilent (Palo Alto, CA, USA) system consisting of a model 6890 gas chromatograph, a model 5973 mass selective detector, and an Agilent ChemStation data system. The GC column was an HP-5 ms fused silica capillary column $(30 \mathrm{~m} \times 0.25 \mathrm{~mm}, 0.25$ $\mu \mathrm{m})$. The carrier gas was helium at a flow rate of $1.0 \mathrm{~mL} / \mathrm{min}$. Oven temperature was $60^{\circ} \mathrm{C}$ for $5 \mathrm{~min}$, and then increased to $250^{\circ} \mathrm{C}$ at a rate of $5^{\circ} \mathrm{C} / \mathrm{min}$. Injector and detector temperatures were 250 and $265^{\circ} \mathrm{C}$, respectively. One microliter of diluted solution was injected into the GC/MS apparatus with a split ratio of $1 / 60$. The ionization energy was $70 \mathrm{eV}$ with a scan time of $1 \mathrm{~s}$ and mass range of 40-540 amu. The percentages of the compounds were calculated by the area normalization method without considering response factors. The components of the oil were identified by comparison of their mass spectra with those of a computer library (NIST database/ChemStation data system) (19).

\section{High-performance liquid chromatography}

The chemical constituents of three extracts were investigated by high-performance liquid chromatography (HPLC) performed according to the literature (17). HPLC analysis was performed using equipment from Shimadazu (Shimadazu, Kyoto, Japan): a Shimadazu LC-2010A liquid chromatograph, a Shimadazu SPD-M10A Diode Array Detector and a Shimadazu Class-vp V6.12 SP4 offline processing system. Flavonoids were analyzed using a Kromasil RP-C18 column (250 x $4.6 \mathrm{~mm}$ ID, $5 \mu \mathrm{m}$; Hanbon Science \& Technology Co., Ltd., Huaiyin, China). The mobile phase consisted of a mixture, methanol-acetonitrile-acetic acid-phosphoric acid$\mathrm{H}_{2} \mathrm{O}$ (200:100:10:10:200, v/v) and the solution was degassed by suction-filtration through a nylon membrane. The detecting wavelength was $352 \mathrm{~nm}$. The flow rate was $0.60 \mathrm{~mL} / \mathrm{min}$ and the sensitivity was set at 0.05 AUFS. The quantity volume of injecting sample was $6.0 \mu \mathrm{L}$. The HPLC system was operated at ambient temperature $\left(28 \pm 1^{\circ} \mathrm{C}\right)$. 


\section{Statistical analysis}

Data are reported as the mean $\pm \mathrm{SD}$ for at least three determinations. Statistical analysis was performed using the Student $t$-test, with the level of significance set at $\mathrm{P}<0.05$.

\section{Results}

$\mathrm{IC}_{50}$

The inhibitory effects of the extracts were determined by exposure of the human nonsmall cell lung carcinoma cell line H1299 and the human hepatocellular carcinoma cell line HepG2 to increasing concentrations of all extracts in a stepwise manner for $72 \mathrm{~h}$. The concentration of each extract which reduced cell survival by $50 \%\left(\mathrm{IC}_{50}\right)$ was deter-

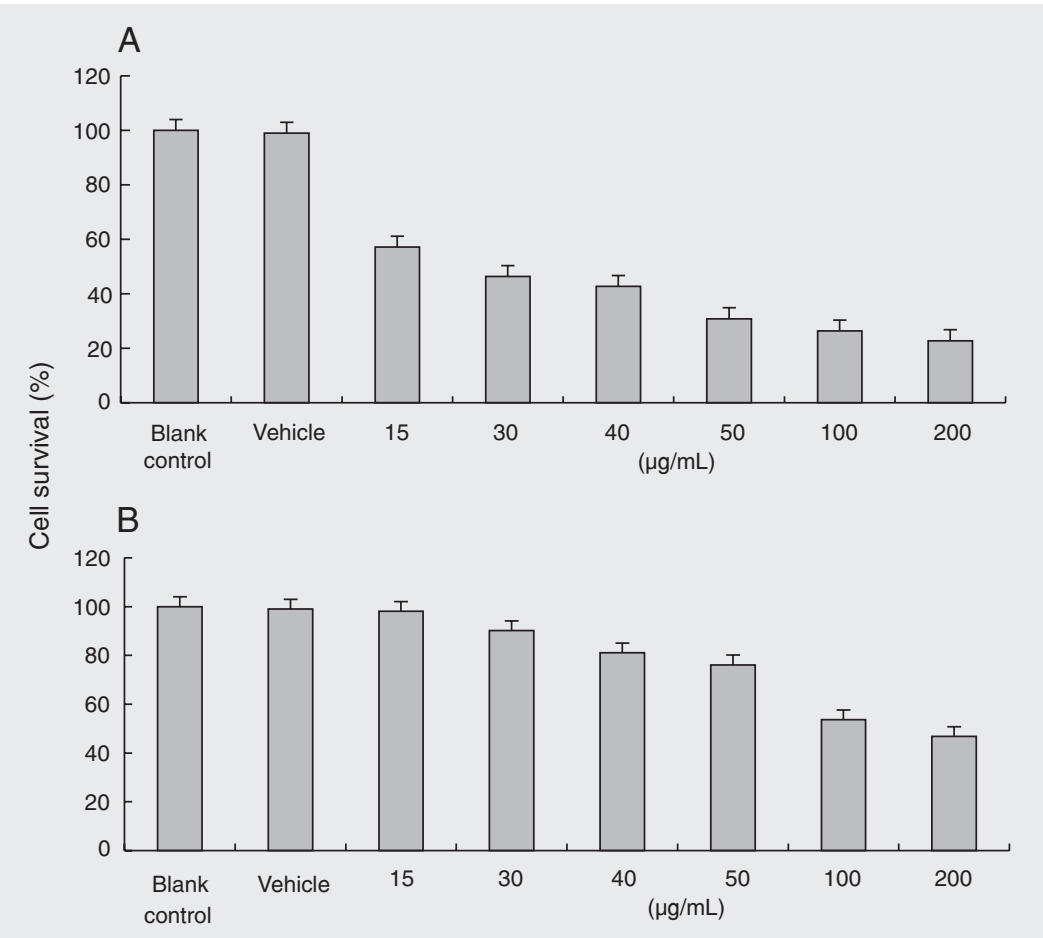

Figure 1. Inhibitory effect of the ethyl acetate extract on H1299 (A) and HepG2 (B). The HepG2 and H1299 cells were seeded on 96-well plates at a final concentration of $5 \times 10^{4}$ cells per $100 \mu \mathrm{L}$ medium per well at $37^{\circ} \mathrm{C}$ to permit cell attachment. After $24 \mathrm{~h}$ the cells were treated with the extracts for $72 \mathrm{~h}$. Then, the medium was removed and $20 \mathrm{~mL}$ MTT (5 mg/ $\mathrm{mL}$ ) in PBS was incubated with cells on a 96-well plate for $2 \mathrm{~h}$ at $37^{\circ} \mathrm{C}$. Subsequently, the medium containing MTT was removed, and $100 \mathrm{~mL}$ of acidified isopropanol $(0.04 \mathrm{~mol} / \mathrm{L}$ $\mathrm{HCl}$ ) was added. The absorbance of each sample was measured at $570 \mathrm{~nm}$.
Table 1. Sensitivity of H1299 and HepG2 cell extracts of Marchantia convoluta.

\begin{tabular}{lcr}
\hline Extract & \multicolumn{2}{c}{$\mathrm{IC}_{50}(\mu \mathrm{g} / \mathrm{mL})$} \\
\cline { 2 - 3 } & $\mathrm{H} 1299$ & HepG2 \\
\hline Petroleum ether & $>500$ & $>500$ \\
Ethyl acetate & 100 & 30 \\
n-butanol & $>200$ & $>200$
\end{tabular}

Cells $\left(5 \times 10^{5} \mathrm{~mL}^{-1}\right)$ were cultured with various amounts of each extract at $37^{\circ} \mathrm{C}$ and $5 \% \mathrm{CO}_{2}$ for $72 \mathrm{~h}$. Cytotoxicity was measured with the MTT assay. $I C_{50}=$ extract concentration causing a $50 \%$ decrease in the survival curve.

mined from cell survival curves and the results are presented in Table 1.

As indicated in Table 1, treatment of H1299 and HepG2 cells with ethyl acetate extract resulted in loss of cell viability, whereas both cell lines were more resistant to the petroleum ether and n-butanol extracts, as shown by the respective $\mathrm{IC}_{50}$ of H1299 and HepG2 cells.

\section{Effect of the ethyl acetate extract on cell proliferation}

The effect of all extracts on different cell lines was studied by measuring cell numbers by the MTT assay after treatment of the cultures with each extract for $72 \mathrm{~h}$. The treatment of all cell lines with the ethyl acetate extract clearly reduced the cell numbers (Figure 1A,B), whereas the petroleum ether and n-butanol extracts did not have an evident inhibitory effect on cell proliferation.

The effect of extracts on cell viability was evaluated by determining the percentage of MTT reduction upon incubation of HepG2 and H1299 cells with increasing extract concentrations in the range $15-200 \mu \mathrm{g} / \mathrm{mL}$. As shown in Figure 1A,B, the ethyl acetate extract produced a dose-dependent reduction in cell viability. Figure 1A shows that a high concentration of ethyl acetate extract $(100 \mu \mathrm{g} /$ $\mathrm{mL}$ ) rapidly reduced the number of H1299 
cells. At lower concentrations of the extract $(15,30$, and $40 \mu \mathrm{g} / \mathrm{mL})$, the numbers of HepG2 cells started to decrease markedly (Figure 1B), whereas no H1299 cell inhibition was observed at the concentration of $15 \mu \mathrm{g} / \mathrm{mL}$. These results suggest that the ethyl acetate extract has an obvious toxic effect on HepG2 cells at low concentrations but inhibits H1299 cells only at higher concentration. The inhibition of proliferation and induction of cell death observed occurred in a concentration- and dosedependent manner.

The petroleum ether and n-butanol extracts of $M$. convoluta had no effect on the human non-small cell lung carcinoma cell line H1299 $\left(\mathrm{IC}_{50}>500\right.$ and $200 \mu \mathrm{g} / \mathrm{mL}$, re- spectively) and human liver carcinoma cell line HepG2 $\left(\mathrm{IC}_{50}>500\right.$ and $200 \mu \mathrm{g} / \mathrm{mL}$, respectively) at any concentration.

\section{Gas chromatography-mass spectrometry}

Extracts of different compositions can be obtained by different extraction methods applied to natural products (20-24). The GCMS profile of the ethyl acetate extract is shown in Figure 2. The separation obtained by GC was excellent. The GC-MS analytical results for the ethyl acetate extract are shown in Table 2.

As shown in Figure 2, a total of eleven compounds accounting for $70.04 \%$ of the

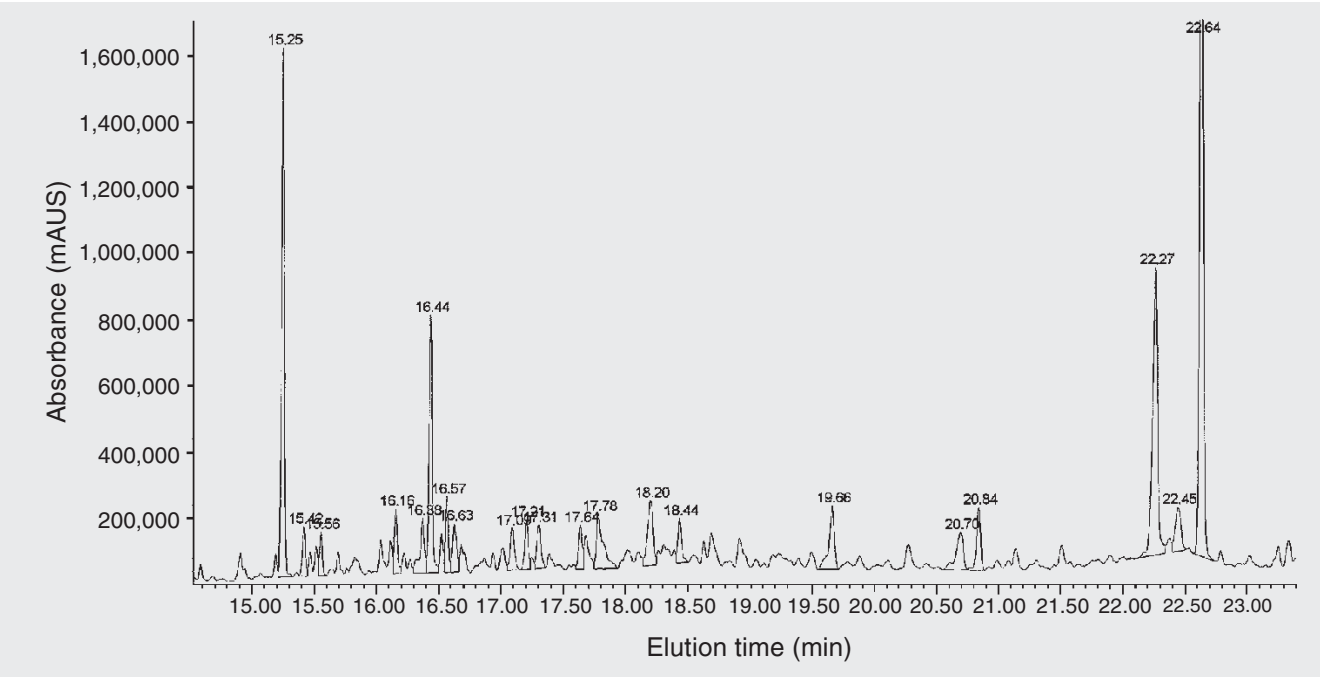

Table 2. Composition of the ethyl acetate extract obtained by GC-MS.

\begin{tabular}{lccc}
\hline Compound & RT/min & Reliability to MS standard & Relative content \\
\hline Caryophyllene & 13.49 & $99 \%$ & $1.82 \%$ \\
9-Cedranone & 15.25 & $90 \%$ & $12.75 \%$ \\
Diepi-alpha-cedrene epoxide & 15.42 & $91 \%$ & $1.37 \%$ \\
Caryophyllene oxide & 15.56 & $93 \%$ & $1.15 \%$ \\
Eudesma-4(14),11-diene & 16.38 & $80 \%$ & $2.27 \%$ \\
Ledene oxide & 16.44 & $90 \%$ & $7.22 \%$ \\
Bi-1-cycloocten-1-yl & 17.21 & $88 \%$ & $1.46 \%$ \\
14-Methylpentadecanoic acid & 19.66 & $98 \%$ & $3.07 \%$ \\
Tetradecanoic acid, methyl ester & 20.84 & $96 \%$ & $2.42 \%$ \\
1,2,4-Tripropylbenzene & 22.27 & $84 \%$ & $13.09 \%$ \\
Phytol & 22.64 & $87 \%$ & $23.42 \%$ \\
\hline
\end{tabular}

RT = Retention time; Reliability to MS standard = match degree $(\%)$ of mass spectrum to the standard compounds; Relative content $=\%$ of total absorbance of all peaks. 
total area were identified in the ethyl acetate extract, which largely consisted of terpenes and their oxo-derivatives. Phytol (23.42\%), 1,2,4-tripropylbenzene (13.09\%), 9-cedranone $(12.75 \%)$, and ledene oxide $(7.22 \%)$ were the major compounds identified in the ethyl acetate extract of $M$. convoluta, with smaller amounts of caryophyllene (1.82\%), and caryophyllene oxide (1.15\%).

\section{HPLC analysis}

HPLC analysis result showed that there were no flavonoids in ethyl acetate extract and petroleum ether extract. As reported in a previous study by our group (17), there were many flavonoids in the n-butanol extract. Some chemical constituents of these extracts could not be identified by GC-MS or HPLC.

\section{Discussion}

Hepatocellular carcinoma is one of the most common malignancies worldwide. The high incidence of liver cancer has been attributed to factors such as persistent infection with hepatitis virus and contact with hepatocarcinogens such as nitrosamines and aflatoxins (25). Because of the multifocal nature of liver carcinoma, most cancer patients are considered non-resectable at presentation. In these patients, chemotherapy is the only choice of treatment. Unfortunately, development of drug resistance in the tumor after treatment is always a major obstacle to the successful management of liver cancer (26).

Non-small cell lung cancers commonly develop resistance to radiation and chemotherapy, and they often cannot be treated by surgical resection. Since current treatment modalities are inadequate, novel therapies are necessary to reduce the effects of the increasing incidence of pulmonary neoplasms (27). Thus, developing new therapeutic agents that can overcome drug resistance is an urgent need for cancer patients.

The leading cause of death in China is cancer, followed by stroke. Conventional western cancer therapies, such as chemotherapy, radiation, and surgery, have been increasingly used since the 1960's in Chinese hospitals. However, the side effects of these treatments have been often highly debilitating both in western countries and in China. The management of cancer with traditional Chinese medicine not only can effectively kill cancer cells, but also has no toxic or side effects on the normal cells of the body. It has no side effect in terms of bone marrow immunosuppression, and has no serious influence on the digestive system. Thus, it could be called "green therapy".

Caryophyllene has shown anti-inflammatory activity in several animal models, including carrageenan- and PGE-induced hind paw edema, which does not require the integrity of adrenal glands (28). ß-caryophyllene seems to have gastric cytoprotective effects in rats (29). Ghelardini et al. (30) found that $\beta$-caryophyllene has a strong local anesthetic action that appears to be strictly dependent on its chemical structure since the oxidized derivative $\beta$-caryophyllene oxide is devoid of this effect. Caryophyllene oxide, an oxygenated terpenoid, well known as a preservative of food, drugs and cosmetics, has been tested in vitro as an antifungal agent against dermatophytes (31). Caryophyllene oxide can reduce rested-state contractions in the presence of isoprenaline which are thought to be due to the $\mathrm{Ca}^{2+}$ current $[\mathrm{I}(\mathrm{Ca})]$ and can inhibit the $\mathrm{I}(\mathrm{Ca})$ in single cells from the guinea-pig ventricle in a concentration-dependent and reversible manner. $\beta$-caryophyllene oxide strongly inhibited the potassium current (32) and $\alpha$ caryophyllene oxide showed strong antimalarial (33) as well as anti-inflammatory activity (34). Caryophyllene oxide has also shown in vitro anti-platelet aggregation activity (35). Sibanda et al. (36) have found caryophyllene oxide to exhibit a modest cytotoxic activity $\left(\mathrm{IC}_{50}\right.$ values ranging from 32.48 to $77.51 \mu \mathrm{g} / \mathrm{mL}$ ) on a panel of human 
tumor cell lines, consistent with an earlier report by Kubo et al. (37). But ethyl acetate extract inhibits liver carcinoma cells with $\mathrm{IC}_{50}$ value of $30 \mu \mathrm{g} / \mathrm{mL}$. So ethyl acetate extract is more potent than caryophyllene oxide.

Caryophyllene oxide, therefore, may be responsible for the cytotoxicity of the ethyl acetate extract against human non-small cell lung carcinoma cell line H1299 and human liver carcinoma cell line HepG2.

The biological activities reported in the literature for the major components of the ethyl acetate extract of $M$. convoluta, i.e., phytol, caryophyllene and caryophyllene oxide, are consistent with the traditional uses of this plant to treat skin tumefaction, to protect the liver and to treat hepatitis B, and as an anticancer drug. The present study indicates that the ethyl acetate extract possesses greater cytotoxicity against HepG2 cells than H1299 cells. Further studies are needed regarding the identification of active compounds and their mechanism of action.

\section{References}

1. Xiao JB, Jiang $X Y$, Chen $X Q$. Antibacterial, anti-inflammatory and diuretic effect of flavonoids from Marchantia convoluta. Afr $\mathrm{J}$ Tradit, Complement Altern Med 2005; 2: 244-252.

2. Jiangsu Institute of Botany. Xinghua Bencao Gangyo. Shanghai: Shanghai Science and Technology Press (in Chinese), 1990.

3. Zou DF, Zhu H, Xiao JB, Cao H, Zhou CS. Identification of UASLG for M. polymorpha, M. convoluta and M. paleacea. Nat Prod Res Develop 2005; 17: 463-464.

4. Asakawa Y. Recent advances in phytochemistry of bryophytesacetogenins, terpenoids and bis(bibenzyl)s from selected Japanese, Taiwanese, New Zealand, Argentinean and European liverworts. Phytochemistry 2001; 56: 297-312.

5. Matsuo A, Nakayama N, Nakayama M. Enantiomeric type sesquiterphenoid of the liverwort Marchantia polymorpha. Phytochemistry 1985; 24: 777-781.

6. Asakawa Y, Tori M, Masuya T, Frahm JP. Ent-sesquiterphenoids and cyclic bis(bibenzyls) from the German liverwort Marchantia polymorpha. Phytochemistry 1990; 29: 1577-1584.

7. Asakawa Y, Okada K, Perold GW. Distribution of cyclic bis(bibenzyls) in the South African liverwort Marchantia polymorpha. Phytochemistry 1988; 27: 161-163.

8. Asakawa Y, Tori M, Takikawa K, Krishnamurty HG, Kar SK. Cyclic bis(bibenzyls) and related compound from the liverwort Marchantia polymorpha. Phytochemistry 1987; 26: 1811-1816.

9. Rieck A, Bülow N, Fricke C, Saritas Y, König WA. (-)-1(10), 11eremophiladien $-9 B-0$ from the liverwort Marchantia polymorpha. Phytochemistry 1997; 45: 195-197.

10. Markham KR, Porter LJ. Flavonoids of the liverwort Marchantia polymorpha. Phytochemistry 1974; 13: 1937-1942.

11. Markham KR, Ryan KG, Bloor SJ, Mitchell KA. An increase in the luteolin: apigenin ratio in Marchantia polymorpha on UV-B enhancement. Phytochemistry 1998; 48: 791-794.

12. Adam KP, Becker H. Phenanthrenes and other phenolics from in vitro cultures of Marchantia polymorpha. Phytochemistry 1994; 35: 139-143.

13. Saruwatari M, Takio S, Ono K. Low temperature-induced accumulation of eicosapentaenoic acids in Marchantia polymorpha cells. Phytochemistry 1999; 52: 367-372.
14. Tian CY, Wu JQ, Liu SX, Hu RL. Characteristics of the bryoflora of Gutianshan nature reserve in Kaihua country, Zhejiang province and comparisons of the bryoflora of the nature reserve and several other nearby mountain areas. Wuhan Bot Res 1999; 17: 179-182 (in Chinese).

15. Zhu H, Xiao JB, Zou DF, Fu P, Zhou CS. Isolation, purification and identification of apigenin-7-O-D-glucuronide in Marchantia convoluta with silica column chromatography, RP-HPLC and LC-ESI-MS. Nat Prod Res Develop 2005; 17: 38-41.

16. Xiao JB, Cao H, Xiang HY, Zhou CS. Determination of the content of flavonoids in Marchantia convoluta. Nat Prod Res Develop 2005; 17: 186-190.

17. Chen XQ, Xiao JB. RP-HPLC-DAD determination of flavonoids: separation of quercetin, luteolin and apigenin in Marchantia convoluta. Iran J Pharmac Res 2005; 4: 175-181.

18. Zhu H, Zhou CS, Huang HB, Wang XX. Studies on the lipophilic constitutes from the leafy body of Marchantia convoluta. Guihaia 2003; 23: 571-573.

19. Adams RP. Identification of essential oil components by gas chromatography/mass spectroscopy. Carol Stream: Allured Publishing; 2001.

20. Pourmortazavi SM, Sefidkon F, Hosseini SG. Supercritical carbon dioxide extraction of essential oils from Perovskia atriplicifolia Benth. J Agric Food Chem 2003; 51: 5414-5419.

21. Stashenko EE, Puertas MA, Combariza M. Volatile secondary metabolites from Spilanthes americana obtained by simultaneous steam distillation-solvent extraction and supercritical fluid extraction. J Chromatogr A 1996; 752: 223-232.

22. Anklam E, Berg $H$, Mathiasson L, Sharman M, Ulberth F. Supercritical fluid extraction (SFE) in food analysis: a review. Food Addit Contam 1998; 15: 729-750.

23. Kohler M, Haerdi W, Christen P, Veuthey JL. Extraction of artemisinin and artemisinic acid from Artemisia annua L. using supercritical carbon dioxide. J Chromatogr A 1997; 785: 353-360.

24. Chester TL, Pinkston JD, Raynie DE. Supercritical fluid chromatography and extraction. Anal Chem 1994; 66: 106R-130R.

25. Henry SH, Bosch FX, Bowers JC. Aflatoxin, hepatitis and worldwide liver cancer risks. Adv Exp Med Biol 2002; 504: 229-233. 
26. Gottesman MM. Mechanisms of cancer drug resistance. Annu Rev Med 2002; 53: 615-627.

27. Kim PK, Park SY, Koty PP, Hua Y, Luketich JD, Billiar TR. Fasassociating death domain protein overexpression induces apoptosis in lung cancer cells. J Thorac Cardiovasc Surg 2003; 125: 13361342.

28. Martin S, Padilla E, Ocete MA, Galvez J, Jimenez J, Zarzuelo A. Anti-inflammatory activity of the essential oil of Bupleurum fruticescens. Planta Med 1993; 59: 533-536.

29. Tambe Y, Tsujiuchi H, Honda G, Ikeshiro Y, Tanaka S. Gastric cytoprotection of the non-steroidal anti-inflammatory sesquiterpene, beta-caryophyllene. Planta Med 1996; 62: 469-470.

30. Ghelardini C, Galeotti N, Di Cesare ML, Mazzanti G, Bartolini A. Local anaesthetic activity of beta-caryophyllene. Farmaco 2001; 56 : 387-389.

31. Yang D, Michel L, Chaumont JP, Millet-Clerc J. Use of caryophyllene oxide as an antifungal agent in an in vitro experimental model of onychomycosis. Mycopathologia 1999; 148: 79-82.

32. Sensch O, Vierling W, Brandt W, Reiter M. Effects of inhibition of calcium and potassium currents in guinea-pig cardiac contraction: comparison of beta-caryophyllene oxide, eugenol, and nifedipine.
Br J Pharmacol 2000; 131: 1089-1096.

33. Thebtaranonth C, Thebtaranonth Y, Wanauppathamkul S, Yuthavong $\mathrm{Y}$. Antimalarial sesquiterpenes from tubers of Cyperus rotundus: structure of 10,12-peroxycalamenene, a sesquiterpene endoperoxide. Phytochemistry 1995; 40: 125-128.

34. Shimizu M, Shogawa H, Matsuzawa T, Yonezawa S, Hayashi T, Arisawa $\mathrm{M}$, et al. Anti-inflammatory constituents of topically applied crude drugs. IV. Constituents and anti-inflammatory effect of Paraguayan crude drug "alhucema" (Lavandula latifolia Vill.). Chem Pharm Bull 1990; 38: 2283-2284.

35. Lin WY, Kuo YH, Chang YL, Teng CM, Wang EC, Ishikawa T, et al. Anti-platelet aggregation and chemical constituents from the rhizome of Gynura japonica. Planta Med 2003; 69: 757-764.

36. Sibanda S, Chigwada G, Poole M, Gwebu ET, Noletto JA, Schmidt $\mathrm{JM}$, et al. Composition and bioactivity of the leaf essential oil of Heteropyxis dehniae from Zimbabwe. J Ethnopharmacol 2004; 92 : 107-111.

37. Kubo I, Chaudhuri SK, Kubo Y, Sanchez Y, Ogura T, Saito T, et al. Cytotoxic and antioxidative sesquiterpenoids from Heterotheca inuloides. Planta Med 1996; 62: 427-430. 